Sains Malaysiana 49(6)(2020): 1303-1312

http://dx.doi.org/10.17576/jsm-2020-4906-08

\title{
Anti-inflammatory Effect of Tamarind Seed Coat Extract against LPS-Induced RAW264.7 Macrophages
}

(Kesan Anti-Keradangan Ekstrak Lapisan Biji Asam Jawa terhadap Penggalak LPS RAW264.7 Makrofaj)

\author{
Jirapa Puntarut, Wipawadee Sianglum, Supita Tanasawet, Pennapa Chonpathompikunlert \& Wanida \\ SUKKETSIRI*
}

\begin{abstract}
Inflammatory response is modulated by stimulated immune cells, and has a pivotal role in host defense system against various stimuli. In this study, we evaluated the anti-inflammatory property of tamarind seed coat extract (TSCE) in lipopolysaccharide (LPS)-induced RAW264.7 macrophages. Various concentrations of TSCE (10, 25, and $\left.50 \mu \mathrm{g} \mathrm{mL} \mathrm{L}^{-1}\right)$

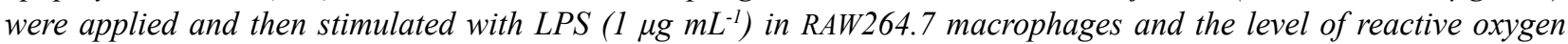
species (ROS) and nitric oxide (NO) were measured. Besides, enzyme-linked immunosorbent assay (ELISA) was used to measure the level of pro-inflammatory cytokines. Our results showed that TSCE suppressed LPS-induced intracellular ROS production and suppressed the NO levels in a dose-dependent manner. Significantly, the anti-inflammatory activity was correlated with a lowered LPS-stimulated TNF- $\alpha$ and IL-1 $\beta$ pro-inflammatory cytokines. These results implied that TSCE possess potent anti-inflammatory activity, which supported new insights into the TSCE utilization to protect inflammation-related disorders.
\end{abstract}

Keywords: Interleukin-1 $\beta$; reactive oxygen species; Tamarindus indica; tumor necrosis factor alpha

\section{ABSTRAK}

Tindak balas keradangan dimodulasi oleh sel-sel imun yang dirangsang dan memainkan peranan penting dalam sistem pertahanan perumah terhadap pelbagai rangsangan. Dalam kajian ini, kami menilai sifat anti-radang daripada ekstrak lapisan biji asam jawa (TSCE) pada lipopolisakarida (LPS) yang diaruh makrofaj RAW264.7. Pelbagai kepekatan TSCE

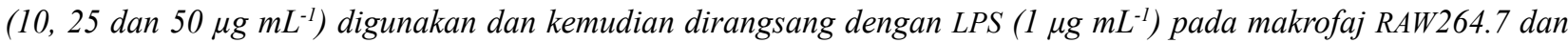
tahap spesies oksigen reaktif (ROS) dan nitrik oksida (NO) diukur. Selain itu, asai imunosorben berkait enzim (ELISA) digunakan untuk mengukur tahap sitokin pro-radang. Hasil kajian menunjukkan bahawa TSCE menindas pengeluaran intraselular ROS yang disebabkan oleh LPS serta menindas aras NO bergantung pada dos atau kepekatan. Aktiviti anti-radang berkorelasi dengan penurunan LPS yang merangsang sitokin pro-radang TNF- $\alpha$ dan IL-1 $\beta$ secara ketara. Hasil ini menunujukkan bahawa TSCE memiliki aktiviti anti-radang yang tinggi sekaligus menyokong pandangan baru tentang penggunaan TSCE dalam melindungi gangguan yang berkaitan dengan keradangan.

Kata kunci: Faktor nekrosis tumor alfa; interleukin-1 $\beta$; spesies oksigen reaktif; Tamarindus indica

\section{INTRODUCTION}

Inflammation is a body's immune system response to harmful stimuli associated with immune cells, molecular negotiators, and inflammatory cytokines. The exposure of pathogen, radiation, extremely high or low temperatures and autoimmune processes induce an inflammation (Ferrero-Miliani et al. 2007; Medzhitov 2010). Chronic inflammatory responses are related to the progression and manifestation of various inflammatory-related diseases, including rheumatoid arthritis, septic syndrome, cardiovascular diseases, cancer and neurodegenerative diseases (Chen et al. 2018).
Lipopolysaccharide (LPS), a potent inflammatory stimulator, is a basic structure of gram-negative bacteria cell wall. It activates host's macrophages to secret inflammatory negotiators, such as nitrite oxide (NO) and pro-inflammatory cytokines, including tumor necrosis factor alpha (TNF- $\alpha$ ), interleukin (IL)-1 $\beta$ (IL-1 $\beta$ ), and IL6 , and subsequently stimulate a cascade of inflammatory response. An excess of chronic inflammatory response triggers the development of various inflammation-related diseases (Chen et al. 2018; Duque \& Descoteaux 2014). In addition, reactive oxygen species (ROS) production by phagocytic cells, for example, neutrophils, monocytes, 
macrophages, and eosinophils is one of the major prominent negotiators in the inflammatory process. ROS stimulation acts as an important and damaging member in abnormal inflammatory diseases (Mittal et al. 2014). Therefore, regulation of macrophage activation is a positive approach to prevent inflammatory-related diseases including rheumatoid arthritis, cardiovascular diseases, cancer and neurodegenerative diseases (Chen et al. 2018). The anti-inflammatory agents which has the ability to reduce the generation of pro-inflammatory negotiators are an effective idea to modulate inflammatory-related diseases.

Tamarindus indica Linn is known as traditional medicinal plants in Thailand and Asian. Their fruits, leaves and seeds have been reported to possesses antimicrobial, anti-inflammatory, hypoglycemic and antioxidant activities (Bhadoriya et al. 2011). Tamarind seed are known as a food industrial by-product and have been used as a coffee substitute (Vadivel \& Pugalenthi 2010). The coat of seed is an abundant source of tannins and polyphenols which possesses anti-allergic and antimicrobial (Aengwanich et al. 2009; Tewtrakul et al. 2008), anti-oxidant (Nakchat et al. 2014; Sandesh et al. 2014; Suksomtip et al. 2010) and anti-inflammatory activities (Ameeramja \& Perumal 2018; Komutarin et al. 2004). To date, the anti-inflammatory activity of tamarind seed coat extract (TSCE) in macrophages have not described. Our present study was therefore aimed to evaluate whether TSCE reduces proinflammatory negotiators in LPS-induced RAW264.7 macrophages.

\section{MATERIALS AND METHODS}

\section{PREPARATION OF TAMARIND SEED COAT}

The seeds of tamarind fruits were collected from Phetchabun, Thailand in May 2015. The seed coats were separated, and one kilograms of tamarind seed coat powder was then extracted using $70 \%$ ethanol in a Soxhlet apparatus for $72 \mathrm{~h}$. After $72 \mathrm{~h}$ of incubation, tamarind seed coat extract (TSCE) was filtered with 0.45 $\mu \mathrm{m}$ filters, concentrated and dried under reduced pressure using a rotary vacuum evaporator. TSCE was then stored at $4{ }^{\circ} \mathrm{C}$ until use.

\section{PHYTOCHEMICAL IDENTIFICATION OF TAMARIND SEED COAT EXTRACT}

The phytochemical constituents such as phenolic compounds, flavonoids, proanthocyanidin and tannins in TSCE were quantified as our previous described (Choosri et al. 2017).

MINIMUM INHIBITION CONCENTRATION (MIC) AND MINIMUM BACTERICIDAL CONCENTRATION (MBC) OF TAMARIND SEED COAT EXTRACT

The MIC and MBC of TSCE were evaluated against gram-positive (Staphylococcus aureus ATCC29213 and Streptococcus mutans ATCC25175) and gram-negative (Escherichia coli ATCC25922). One hundred microliter of bacterial suspension $\left(10^{6} \mathrm{CFU} \mathrm{mL} \mathrm{mL}^{-1}\right)$ were incubated with $5 \mathrm{~mL}$ of Muller Hinton broth. Afterthought, TSCE were added and incubated for $24 \mathrm{~h}$ at $37^{\circ} \mathrm{C}$.

\section{CELL CULTURE AND REAGENTS}

RAW264.7 cell was provided from the American Type Culture Collection (Manassas, VA, USA). Dulbecco's modified Eagle's medium (DMEM) (Gibco, USA) containing $10 \%$ fetal bovine serum (FBS), 1\% antibiotic (penicillin/streptomycin) and $1 \%$ L-glutamine (Gibco, USA) was used to maintain RAW264.7 cell in a $5 \% \mathrm{CO}_{2}$ incubator at $37{ }^{\circ} \mathrm{C}$. Dexamethasone, $2^{\prime}, 7^{\prime}$-dichlorofluorescein diacetate (DCFH-DA), dimethylsulfoxide and lipopolysaccharide (LPS) from Escherichia coli 055:B5 were provided from Sigma (St. Louis, MO, USA).

\section{CYTOTOXICITY OF TAMARIND SEED COAT EXTRACT (TSCE)}

\section{ON RAW264.7 CELLS}

RAW264.7 macrophages $\left(1 \times 10^{4}\right.$ cells/well $)$ were cultured into 96-well plate with the complete DMEM medium. After $24 \mathrm{~h}$ of incubation, TSCE at the concentration of $0,1,5,10,25,50,100,250,500$, and $1000 \mu \mathrm{gL}^{-1}$ were then treated to the cells for $24 \mathrm{~h}$. The RAW264.7 cells viability of TSCE-treated was measured by using a colorimetric MTT assay, and the optical density (OD) of each concentration was detected with a microplate reader at $570 \mathrm{~nm}$ (Bio-Tex Instruments, Inc., VT, USA).

MEASUREMENT OF NITRIC OXIDE (NO) LEVEL IN RAW264.7 CELLS

RAW264.7 macrophages $\left(1 \times 10^{5}\right.$ cells/well $)$ were incubated with TSCE $\left(10,25\right.$, and $\left.50 \mu \mathrm{g} \mathrm{mL}^{-1}\right)$ in with or without $1 \mu \mathrm{g} \mathrm{mL}^{-1}$ of LPS for $24 \mathrm{~h}$. Next, Griess reagent was used to evaluate a nitrite level in the culture medium of RAW264.7 macrophages. Concisely, 100 $\mu \mathrm{L}$ of Griess reagent was mixed with an equivalent volume of media. The OD of the nitrite-containing samples was assessed with a microplate reader at $540 \mathrm{~nm}$ (Bio-Tex Instruments, Inc., VT, USA). A standard curve was marked from sodium nitrite solution.

\section{MEASUREMENT OF INTRACELLULAR REACTIVE OXYGEN \\ SPECIES (ROS) PRODUCTION IN RAW264.7 CELLS}

The oxidation of DCFH-DA was used for determining the intracellular ROS production in RAW264.7 cells. In brief, RAW264.7 cells $\left(5 \times 10^{4}\right.$ cells/well $)$ were grown in 96-well plate and then treated with TSCE $(10,25$, and $\left.50 \mu \mathrm{g} \mathrm{mL}^{-1}\right)$ in the presence or absence of LPS for 24 h. Then, $50 \mu \mathrm{M}$ of DCFH-DA was mixed and incubated for $1 \mathrm{~h}$, at $37^{\circ} \mathrm{C}$ in dark condition. DCF fluorescence was 
detected at an excitation wavelength of $485 \mathrm{~nm}$ and an emission wavelength of $530 \mathrm{~nm}$ using a fluorescence microplate reader (Bio-Tex Instruments, Inc., VT, USA).

\section{MEASUREMENT OF TNF- $\alpha$ AND IL-1 $\beta$ LEVEL IN RAW264.7}

\section{CELLS}

RAW264.7 cells $\left(1 \times 10^{5}\right.$ cells/well $)$ were maintained in 96-well plate and incubated for $24 \mathrm{~h}$. TSCE $(10,25$, and $\left.50 \mu \mathrm{g} \mathrm{mL}^{-1}\right)$ and dexamethasone $\left(1 \mu \mathrm{g} \mathrm{mL}^{-1}\right)$ were treated in the presence or absence of LPS for $24 \mathrm{~h}$ in RAW264.7 cells. After $24 \mathrm{~h}$ of incubation, TNF- $\alpha$ and IL-1 $\beta$ level in RAW264.7 cells cultured medium were measured by using ELISA method.

\section{STATISTICAL ANALYSIS}

The results were shown as mean \pm standard error of mean (SEM). ANOVA was applied for measuring the differences of the mean values between four groups with Tukey post hoc test and $p<0.05$ was used to be statistically significant.

\section{RESULTS}

\section{PHYTOCHEMICAL PROFILE OF TAMARIND SEED COAT} EXTRACT (TSCE)

As shown in Table 1, the preliminary phytochemical screening of TSCE showed the presence of phenolic compound, flavonoid, proanthocyanidin and tannin contents. Total phenolic compounds concentration was $26.43 \pm 0.56 \mathrm{mg}$ of gallic acid equal per $100 \mathrm{~g}$ of dry extract. The concentration of total flavonoids was $3.54 \pm 0.06 \mathrm{mg}$ of quercetin equal per $100 \mathrm{~g}$. The content of proanthocyanidin was $1.43 \pm 0.08$ whereas tannin content was showed at $21.49 \pm 1.49 \%$ pyrogallol equal, respectively. Our results suggested that TSCE presented a high concentration of phenolic compounds and tannin contents.

\section{MIC AND MBC OF TAMARIND SEED COAT EXTRACT}

Minimum inhibition concentration (MIC) values of TSCE was measured as an assessment of antimicrobial activity against pathogenic bacteria. The antimicrobial activity of TSCE were determined against two pathogenic bacterial strains, gram-positive (Staphylococcus aureus ATCC29213 and Streptococcus mutans ATCC25175) and gram-negative (Escherichia coli ATCC25922). MIC values as evaluated by the broth dilution method was 64 $\mu \mathrm{g} \mathrm{mL} \mathrm{m}^{-1}$ for $S$. aureus as the most susceptible bacteria, while $E$. coli was more resistant because their growth was inhibited in the concentration more than $1204 \mu \mathrm{g} \mathrm{mL}^{-1}$ (Table 2).
CYTOTOXICITY EFFECT OF TSCE ON RAW264.7 CELLS

In order to evaluate the cytotoxicity of TSCE on macrophages, RAW264.7 cells were incubated with TSCE at concentrations $0-1,000 \mu \mathrm{g} \mathrm{mL}{ }^{-1}$ for $24 \mathrm{~h}$. As shown in Figure 1, 1-50 $\mu \mathrm{g} \mathrm{mL}^{-1}$ of TSCE did not affect RAW264.7 cells viability after $24 \mathrm{~h}$ treatment. The percentage of cell viability was significantly decreased after administration with 75-1000 $\mu \mathrm{g} \mathrm{mL}^{-1} \mathrm{TSCE}$ in a concentration-dependent manner when compared to the untreated group. $\mathrm{IC}_{50}$ of $24 \mathrm{~h}$ was $76.28 \pm 0.09 \mu \mathrm{g} \mathrm{mL}^{-1}$ (Figure 1(A))

\section{TSCE DECREASED THE ROS PRODUCTION IN LPS-INDICED RAW264.7 CELLS}

Reactive oxygen species (ROS) is a key molecule that plays an important role in the progression of the inflammatory disorders (Mittal et al. 2014). We evaluated whether TSCE could reduce intracellular ROS which are noted to stimulate inflammatory process. As shown in Figure 1B, LPS caused a significant increased $(\mathrm{p}<0.001)$ in the production of intracellular ROS in RAW264.7 macrophages compare to the untreated control. TSCE at the concentration of 25 and $50 \mu \mathrm{g} \mathrm{mL}^{-1}$ significantly decreased the percentage of LPS-induced intracellular ROS generation in RAW264.7 cells in a concentrationdependent manner compared to the untreated control group. While dexamethasone treatment did not decrease the percentage of LPS-induced intracellular ROS production in RAW264.7 cells (Figure 1(B)).

\section{TSCE INHIBITS LPS-INDUCED NITRIC OXIDE (NO) LEVEL IN RAW264.7 CELLS}

$\mathrm{NO}$ is a key signaling molecules that plays a major role in the pathogenesis of inflammation (Sharma et al. 2007). We investigated whether TSCE could reduce the NO level which are known to stimulate the progression of inflammatory process. As shown in Figure 2(A), LPS caused a significantly increased nitrite level, as an index of NO in cultured medium of RAW264.7 macrophages $(p<0.001)$ compared to the untreated control group. Interestingly, TSCE at the concentration of 10, 25 and $50 \mu \mathrm{g} \mathrm{mL}^{-1}$ caused a significant diminish $(\mathrm{p}<0.001)$ the nitrite content in LPS-induced RAW264.7 macrophages (Figure 2(A)) and also increased \% NO inhibition with $\mathrm{IC}_{50}$ value of $24 \mathrm{~h}$ were $32.85 \pm 7.79 \mu \mathrm{g} / \mathrm{mL}$ (Figure $2(\mathrm{~B})$ ) when compared to the untreated group. Dexamethasone (1 $\left.\mu \mathrm{g} \mathrm{mL}^{-1}\right)$ as a positive drug significantly decreased the nitrite content in LPS-induced RAW264.7 macrophages.

\section{TSCE SUPPRESSED LPS-INDUCED TNF- $\alpha$ AND IL-1 $\beta$ PRODUCTION IN RAW264.7 CELLS}

As shown in Figures 3(A) and 4(A), LPS caused a significantly increased the secretion of IL-1 $\beta$ and 
TNF- $\alpha$ in RAW264.7 macrophages. Significantly, TSCE at the concentration of 10,25 , and $50 \mu \mathrm{g} \mathrm{mL} \mathrm{m}^{-1}$ caused a significant reduction of IL-1 $\beta$ secretion $(p<0.001)$ (Figure 3(A)) when compared to the untreated group and increased \% IL-1 $\beta$ inhibition with $\mathrm{IC}_{50}$ value of 24 $\mathrm{h}$ were $28.33 \pm 3.77$ (Figure 3(B)). In addition, TSCE at the concentration of 10,25 , and $50 \mu \mathrm{g} \mathrm{mL}^{-1}$ significantly decreased the release of TNF- $\alpha \quad(p<0.001)$ (Figure 4(A)) in LPS-induced RAW264.7 macrophages when compared to the untreated group and enhanced $\%$ TNF- $\alpha$ inhibition with $\mathrm{IC}_{50}$ value of $24 \mathrm{~h}$ were $53.49 \pm 9.04 \mu \mathrm{g} \mathrm{mL}^{-1}$ (Figure 4(B)). Dexamethasone $\left(1 \mu \mathrm{g} \mathrm{mL}^{-1}\right)$ significantly decreased the IL- $1 \beta$ and TNF- $\alpha$ level in LPS-induced RAW264.7 macrophages (Figures 3 and 4). We further confirmed that TSCE decrease the level of inflammatory mediators (NO, ROS, IL- $1 \beta$, and TNF- $\alpha$ ) was not due to chemically activated cytotoxicity. The results presented that cell viability of LPS in with or without of 10,25, and $50 \mu \mathrm{g} \mathrm{mL}^{-1}$ of TSCE as well as dexamethasone $\left(1 \mu \mathrm{g} \mathrm{mL}^{-1}\right)$ was not significantly decreased (Figure 5). Accordingly, this result indicated that TSCE could decrease the LPSinduced inflammatory response in RAW264.7 cells by inhibiting the production of proinflammatory mediators.

TABLE 1. Phytochemical screening of phenolic compound, flavonoid, proanthocyanidin, and tannin in tamarind seed coat extract (TSCE)

\begin{tabular}{|c|c|c|c|c|}
\hline & $\begin{array}{c}\text { Total phenolic } \\
\text { compound } \\
\text { (g GAE } / 100 \text { g dry } \\
\text { extract) }\end{array}$ & $\begin{array}{c}\text { Flavonoid content } \\
\text { (g quercetin/100 g dry } \\
\text { extract) }\end{array}$ & $\begin{array}{l}\text { Proanthocyanidin } \\
\text { (A500) in } 100 \mu \mathrm{g} \mathrm{mL}^{-1}\end{array}$ & $\begin{array}{c}\text { Tannin } \\
(\% \text { pyrogallol equivalent })\end{array}$ \\
\hline TSCE & $26.43 \pm 0.56$ & $3.54 \pm 0.06$ & $1.43 \pm 0.08$ & $21.49 \pm 1.49$ \\
\hline
\end{tabular}

Values express in mean \pm SEM from three observations

TABLE 2. Antibacterial activity of tamarind seed coat extract (TSCE)

\begin{tabular}{lcc}
\hline Bacterial strains & $\begin{array}{c}\text { Minimal inhibitory } \\
\text { concentration } \\
\left(\mu \mathrm{gL} \mathrm{m}^{-1}\right)\end{array}$ & $\begin{array}{c}\text { Minimal bactericidal concentration } \\
\left(\mu \mathrm{g} \mathrm{mL} \mathrm{m}^{-1}\right)\end{array}$ \\
\hline Staphylococcus aureus ATCC29213 & 64 \\
Streptococcus mutans ATCC25175 & 128 \\
Escherichia coli ATCC25922 & $>1204$ \\
\hline
\end{tabular}


(A)

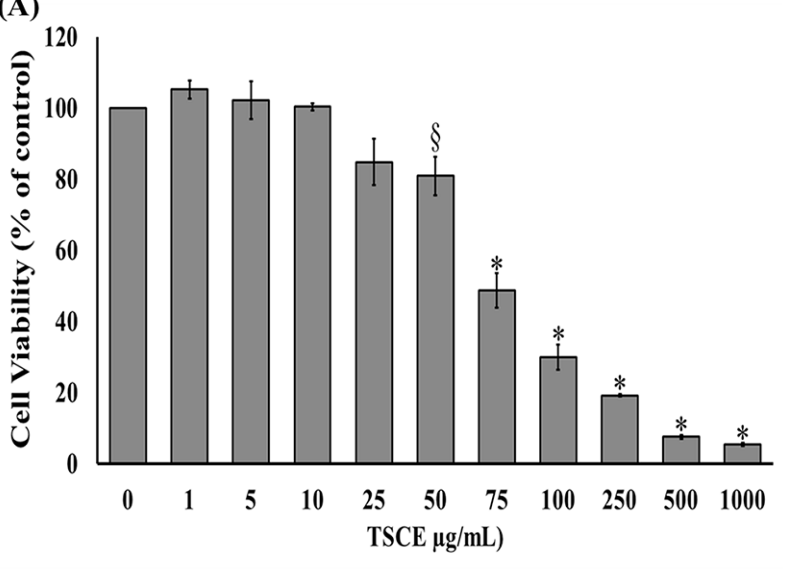

(B)

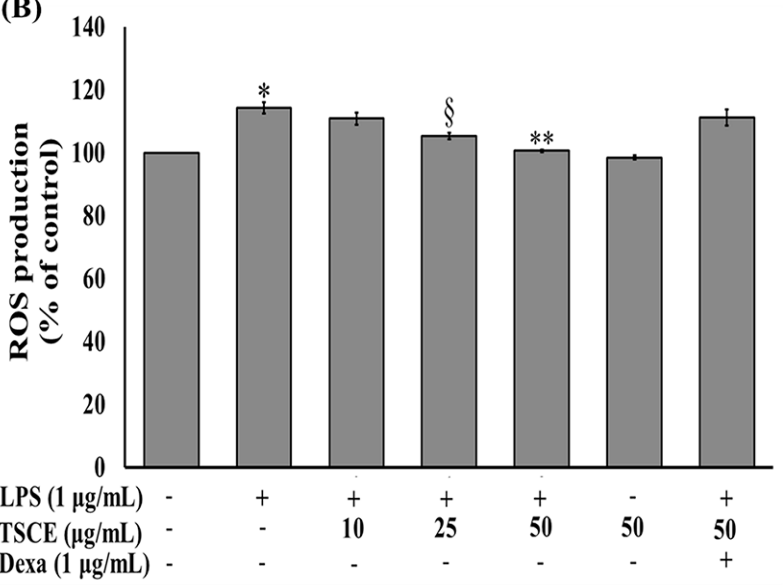

FIGURE 1. Effect of the tamarind seed coat extract (TSCE) on cytotoxicity and intracellular ROS production in RAW264.7 macrophages. (A) RAW264.7 cells were treated with $0,1,5,10$, $25,50,100,250,500$, and $1000 \mu \mathrm{g} \mathrm{mL}^{-1}$ of TSCE for $24 \mathrm{~h}$. The RAW264.7 cells viability of TSCE-treated was measured by using a colorimetric MTT assay. (B) TSCE decreased the ROS production in LPS-induced RAW264.7 cells. Cells were treated with TSCE $(10,25$, and $50 \mu \mathrm{g}$ $\left.\mathrm{mL}^{-1}\right)$ in the presence or absence of LPS for $24 \mathrm{~h}$. Data are presented as mean \pm S.E.M. for four independent experiments. ${ }^{*} \mathrm{p}<0.05$ compared to the $0 \mu \mathrm{g} \mathrm{mL}{ }^{-1}{ }^{*} \mathrm{p}<0.001$ compared to the 0 $\mu \mathrm{g} \mathrm{mL}{ }^{-1} . \S \mathrm{p}<0.001$ compared to the untreated group. ${ }^{\S} \mathrm{p}<0.05$ compared to the LPS group.

$* * \mathrm{p}<0.001$ compared to the LPS group

(A)

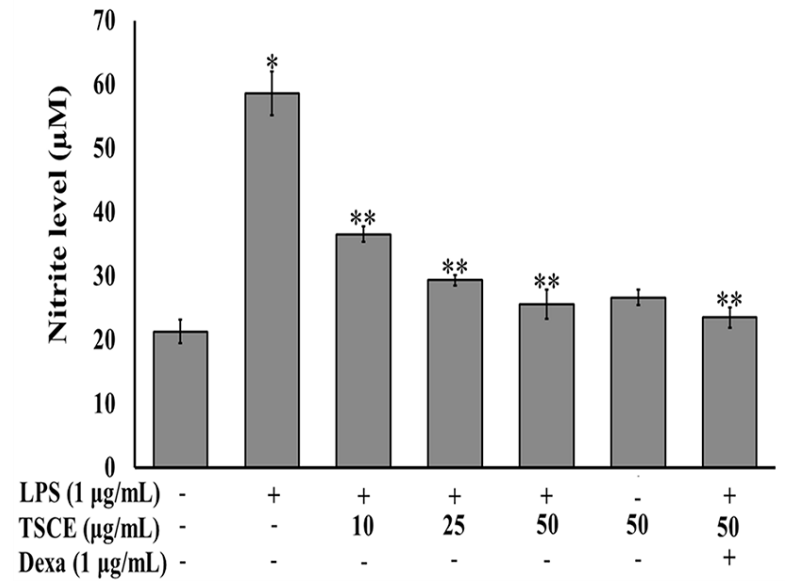

(B)

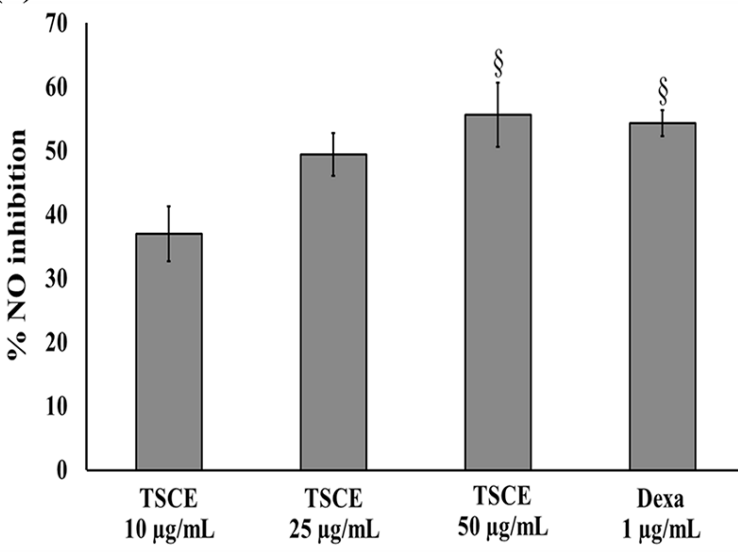

FIGURE 2. Tamarind seed coat extract (TSCE) inhibits LPS-induced NO production (A) and increases \% NO inhibition (B) in RAW264.7 macrophages. RAW264.7 macrophages were received TSCE $\left(10,25\right.$, and $\left.50 \mu \mathrm{g} \mathrm{mL}^{-1}\right)$ in the presence or absence of LPS for 24 h. Data are presented as mean \pm S.E.M. for four independent experiments. ${ }^{*} \mathrm{p}<0.001$ compared to the untreated control group. ${ }^{* *} \mathrm{p}<0.001$ compared to the LPS group. $\S p<$ 0.05 compared to the $10 \mu \mathrm{g} \mathrm{mL}^{-1}$ of TSCE 
(A)

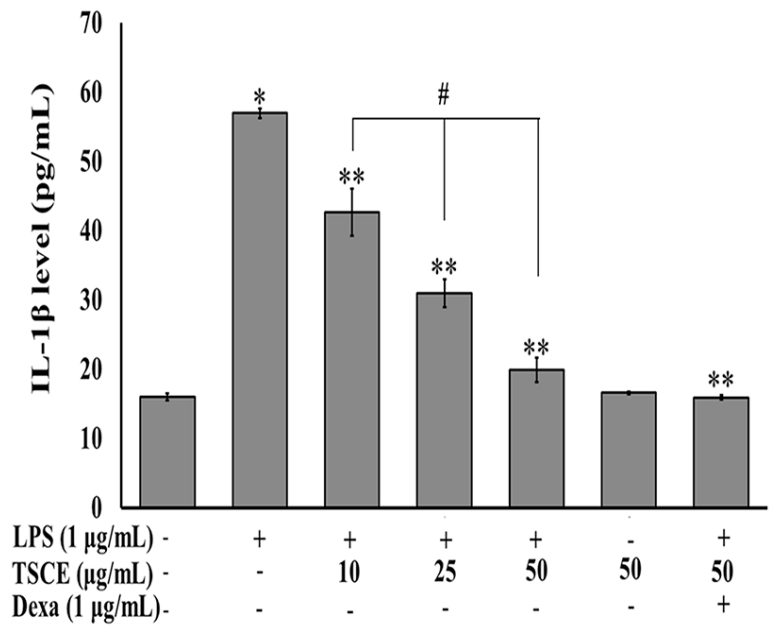

(B)

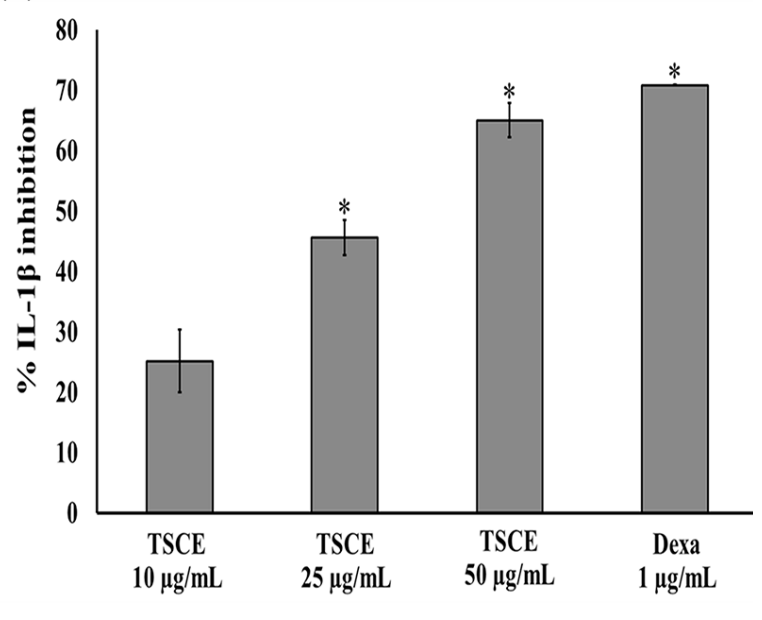

FIGURE 3. Tamarind seed coat extract (TSCE) inhibits LPS-induced IL-1 $\beta$ level (A) and increases \% IL-1 $\beta$ inhibition (B) in RAW264.7 macrophages. RAW264.7 macrophages were administered TSCE $\left(10,25\right.$, and $\left.50 \mu \mathrm{g} \mathrm{mL}^{-1}\right)$ in the presence or absence of LPS for $24 \mathrm{~h}$.

Data are presented as mean \pm S.E.M. for four independent experiments. $\# \mathrm{p}<0.05$ difference between treatment groups. ${ }^{*} p<0.001$ compared to the untreated control group. ${ }^{* *} p<0.001$ compared to the LPS group. ${ }^{*} \mathrm{p}<0.001$ compared to the $10 \mu \mathrm{g} \mathrm{mL}{ }^{-1}$ of TSCE

(A)

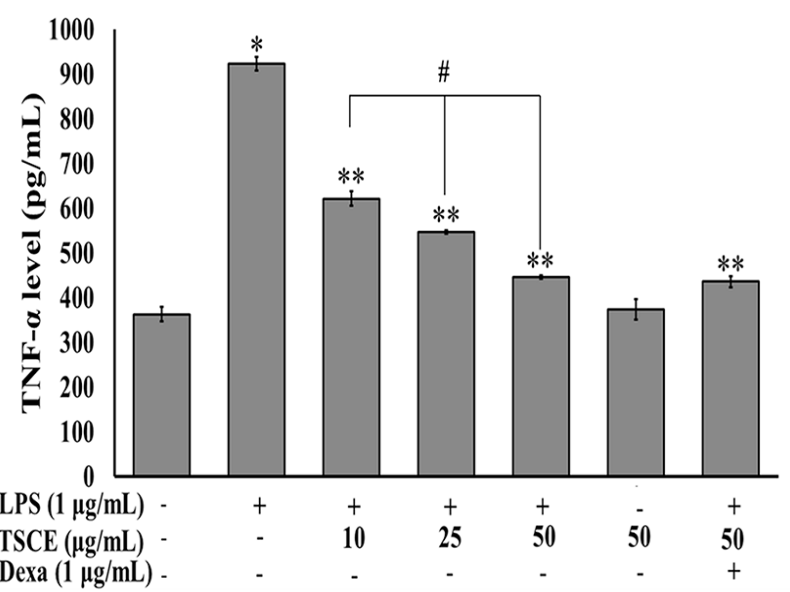

(B)

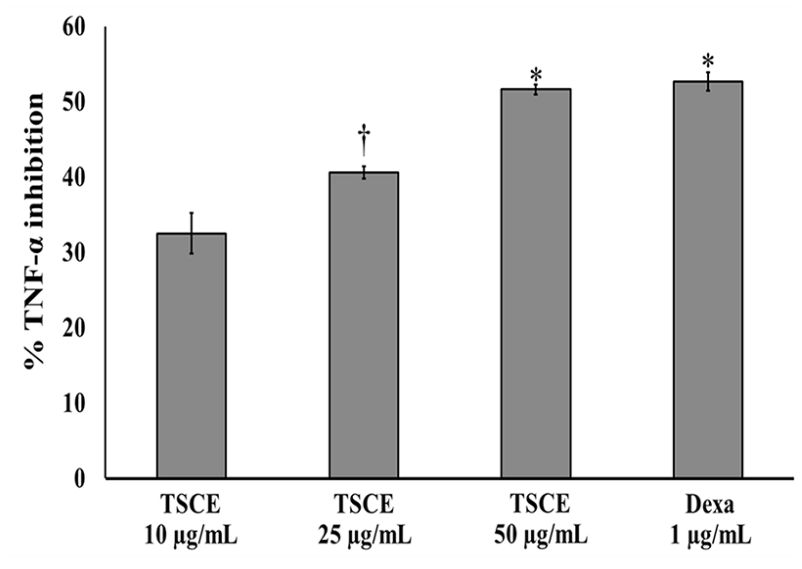

FIGURE 4. Tamarind seed coat extract (TSCE) inhibits LPS-induced TNF- $\alpha$ level (A) and increases \% TNF- $\alpha$ inhibition (B) in RAW264.7 macrophages. RAW264.7 macrophages were administered TSCE $\left(10,25\right.$, and $\left.50 \mu \mathrm{g} \mathrm{mL}^{-1}\right)$ in the presence or absence of LPS for $24 \mathrm{~h}$. Data are presented as mean \pm S.E.M. for four independent experiments. $\# \mathrm{p}<0.05$ difference between treatment groups. $+\mathrm{p}<0.001$ compared to the untreated control group. ${ }^{* *} \mathrm{p}<0.001$ compared to the LPS group. ${ }^{*} \mathrm{p}<0.01$ compared to the $10 \mu \mathrm{g} \mathrm{mL}{ }^{-1}$ of TSCE. ${ }^{*} \mathrm{p}<0.001$ compared to the $10 \mu \mathrm{g} \mathrm{mL}^{-1}$ of TSCE 


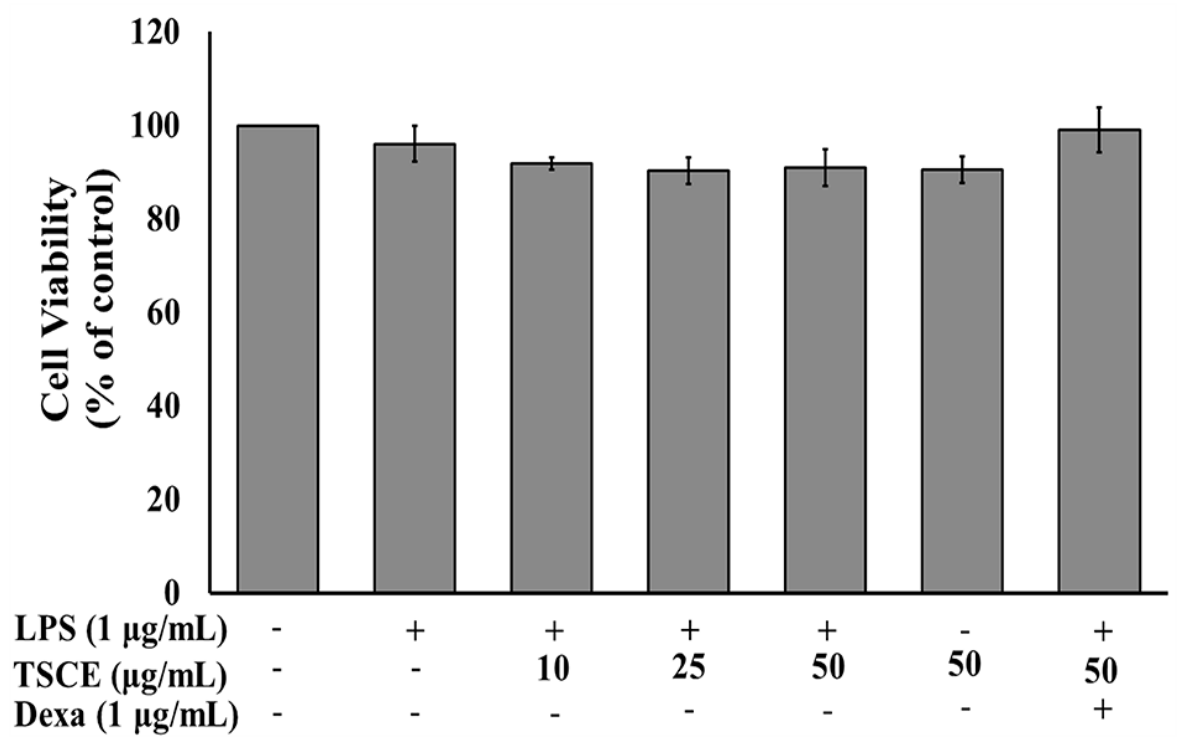

FIGURE 5. Effect of TSCE $\left(10,25\right.$, and $\left.50 \mu \mathrm{g} \mathrm{mL}^{-1}\right)$ in the presence or absence of LPS on cytotoxicity in RAW264.7 macrophages. Cytotoxicity was evaluated by MTT assay. Data are presented as mean \pm S.E.M. for four independent experiments

\section{DISCUSSION}

Plants and their extracts containing phenolics, flavonoids or tannin were extensively used as traditional drugs to restrain and treat inflammatory diseases in Asian for a long time (Wiart 2007). Natural phenolics, flavonoids or tannin have been noted to display anti-inflammatory activities in vitro (Park et al. 2014; Sergent et al. 2010) and in vivo (Alinejhad et al. 2016; Jayaraman et al. 2012). It has been indicated that natural extract could develop as new anti-inflammatory agents. The seed coat of tamarind has been described to protect fluoride-stimulated pulmonary inflammation and fibrosis (Ameeramja \& Perumal 2018). However, the effects of tamarind seed coat extract in macrophages have not been studied. The aimed of this study was to evaluate the preliminary studies on anti-inflammatory capabilities of tamarind seed coat extract (TSCE) in LPS-induced RAW264.7 macrophages. The findings from our study provide an evidence of anti-inflammatory of TSCE effectiveness in the RAW264.7 cell culture model.

The phytochemical evaluation of tamarind seed extract has been reported on the presence of many active components including procyanidin B2, catechin, rutin, embelin, arecatannin B1, D-threo-isocitric acid and galactosyl glycerol (Sundaram et al. 2015). Procyanidin, catechin, rutin and embelin have been revealed to be an effective anti-oxidant and anti-inflammatory properties, which are capable of inhibiting oxidative stress (Babu
\& Liu 2008; Martinez-Micaelo et al. 2012; Schaible et al. 2013). Moreover, polyphenols and tannins display antioxidant, antibacterial, and anti-inflammatory action (Tungmunnithum et al. 2018). Our results on phytochemical screening reported that TSCE contained the presence of tannins, flavonoids, proanthocyanidin and polyphenols which is consistent with previous reports (Bhadoriya et al. 2018; Nakchat et al. 2014a).

The gram-positive strains of $S$. aureus ATCC29213 was more sensitive to the activity of TSCE but it was not effective against the gram-negative strain of $E$. coli ATCC25922. The MIC of TSCE was also investigated and its value was $64 \mu \mathrm{g} \mathrm{mL}-1$ for strains $S$. aureus ATCC29213 which is consistent with previous reports (Lima et al. 2017). However, gram-negative are more resistant with MIC values of $>1204 \mu \mathrm{g} \mathrm{mL}^{-1}$ for $E$. coli ATCC25922. Antibacterial properties of plant extracts in gram-negative are more resistant than gram-positive might due to the presence of the chemical composition of cell wall. Gram-negative membrane causes rigidity and inhibits the bioactive compounds penetration into the bacteria.

LPS could be stimulated RAW264.7 macrophages and then secreted enormous amounts of the inflammatory negotiators, including ROS, NO and the pro-inflammatory cytokines, such as TNF- $\alpha$ and IL-1 $\beta$ (Sukketsiri et al. 2019). These inflammatory negotiators play pivotal functions in the development of inflammatory diseases (Duque \& 
Descoteaux 2014). The suppression of LPS-encouraged inflammatory negotiators is noted as an ameliorative approach for the protection of inflammation (Sukketsiri et al. 2019). Hence, ROS, NO, TNF- $\alpha$, and IL- $1 \beta$ were selected to determine the anti-inflammatory property of TSCE in this study. Furthermore, the anti-inflammatory activities of TSCE are demonstrated quantitatively using the $\mathrm{IC}_{50}$ value, which is the TSCE concentration desired to restrict $50 \%$ generation of these LPStriggered inflammatory negotiators. The $\mathrm{IC}_{50}$ value was accessed from the graph of the percentage of inhibited inflammatory negotiators and the TSCE concentration. Hence, the $\mathrm{IC}_{50}$ value for the TSCE in this experiment on the suppression of the inflammatory negotiators could be used to determined anti-inflammatory properties of the TSCE.

ROS are important for host defense mechanism and are generated by phagocytes in reaction to microbial and inflammatory stimuli (Leavy 2014). ROS are crucial signaling molecules that show a significant function in the advancement of inflammatory disorders. An excessive of ROS causes the stimulation of pro-inflammatory cytokines (Bryan et al. 2012; Schieber \& Chandel 2014). Furthermore, ROS is also a secondary messenger augmented in response to LPS-induced inflammation (Sukketsiri et al. 2019). Accordingly, modulation of ROS is an essential target for approving the machinery of inflammatory stimulation. We found that TSCE could significantly attenuated the production of ROS in LPS-induced RAW264.7 macrophages which was in line with the previous reports (Ameeramja et al. 2016; Nakchat et al. 2014b). This effect of TSCE might due to its components, for example, phenolic, procyanidins, flavonoids and tannin which have reported to possesses antioxidant by elevated the non-enzymatic and enzymatic antioxidant system (Ameeramja et al. 2016; Nakchat et al. 2014a, 2014b).

In the inflammation process, NO is known as a proinflammatory negotiator that promotes inflammation due to excessive generation in abnormal conditions (Sharma et al. 2007). Thus, natural compounds able to be suppressing the generation of $\mathrm{NO}$ would be significant in restraining the occurrence of inflammatory disorder. TSCE has been reported to decrease NO level in fluoride-stimulated pulmonary inflammation in rats' model (Ameeramja \& Perumal 2018). In this experiment, our results positively showed that TSCE significantly attenuated the level of NO secretion in LPS-encouraged RAW264.7 macrophages. Interestingly, TSCE are seemingly powerful with $\mathrm{IC}_{50}=32.85 \pm 7.79 \mu \mathrm{g} \mathrm{mL}^{-1}$ in the suppression of NO generation in LPS-encouraged RAW264.7 macrophages. It might be postulated that the phenolic and tannin compounds at high concentrations in the TSCE might responsible for the strong inhibitory activity against NO generation. TSCE is considered as a promising functional food product by suppressing the generation of NO.

It has been noted that TNF- $\alpha$ and IL-1 $\beta$ proinflammatory cytokines are in associated with numerous inflammatory diseases (Chen et al. 2018; Duque \& Descoteaux 2014). TNF- $\alpha$ is an important cytokine that activates macrophages through enhancing other pro-inflammatory cytokines in the progression of inflammation (Duque \& Descoteaux 2014). IL-1 $\beta$ acts as an activator to enhance the secretion of inflammatory proteins during inflammation (Chen et al. 2018). Consequently, inhibitors of TNF- $\alpha$ and IL- $1 \beta$ have also been suggested as patterns for the anti-inflammatory drugs development. In this study, we measured the properties of TSCE on the TNF- $\alpha$ and IL- $1 \beta$ secretion in LPS-encouraged RAW264.7 macrophages. We found that TSCE considerably attenuated the release of both TNF- $\alpha$ and IL-1 $\beta$. Significantly, TSCE is capable in lowering the TNF- $\alpha$ secretion with $\mathrm{IC}_{50}=53.49 \pm 9.04$ $\mu \mathrm{g} \mathrm{mL} \mathrm{m}^{-1}$ in LPS-encouraged RAW264.7 macrophages. Additionally, TSCE is show in inhibiting the IL-1 $\beta$ secretion with $\mathrm{IC}_{50}=28.33 \pm 3.77 \mu \mathrm{g} \mathrm{mL} \mathrm{mL}^{-1}$ in LPSencouraged RAW264.7 macrophages. Interestingly, TSCE showed higher suppression in lowering the secretion of IL-1 $\beta\left(\mathrm{IC}_{50}=28.33 \pm 3.77 \mu \mathrm{g} \mathrm{mL} \mathrm{L}^{-1}\right)$ than TNF- $\alpha\left(\mathrm{IC}_{50}\right.$ $=53.49 \pm 9.04 \mu \mathrm{g} \mathrm{mL}^{-1}$ ) in this study model. Hence, our study suggested that TSCE could decrease the inflammatory response by diminishing the generation of proinflammatory cytokines IL- $1 \beta$ and TNF- $\alpha$.

\section{CONCLUSION}

TSCE provided a potent anti-inflammatory property though the reduction of ROS, NO, IL- $1 \beta$ and TNF- $\alpha$. Based on our results, we indicate TSCE might be a good candidate to develop as an anti-inflammatory drug; however, further investigations on the specific molecular mechanisms responsible for the anti-inflammatory effect of TSCE are still needed to clarify.

\section{ACKNOWLEDGMENTS}

The study was supported by the grant from the Agricultural Research Development Agency (no. CRP5605020930), Bangkok, Thailand.

\section{REFERENCES}

Aengwanich, W., Suttajit, M., Srikhun, T. \& Boonsorn, T. 2009. Antibiotic effect of polyphenolic compound extracted from tamarind (Tamarindus indica L.) seed coat on productive performance of broilers. International Journal of Poultry Science 8(8): 749-751.

Alinejhad, D., Asayesh, M.A. \& Asayesh, M. 2016. Determination of the anti-inflammatory property of tannins from the rind of calamansi (Citrus microcarpa, Rutaceae). Journal of International Oral Health 8(5): 546-553. 
Ameeramja, J. \& Perumal, E. 2018. Possible modulatory effect of tamarind seed coat extract on fluoride-induced pulmonary inflammation and fibrosis in rats. Inflammation 41(3): 886895.

Ameeramja, J., Panneerselvam, L., Govindarajan, V., Jeyachandran, S., Baskaralingam, V. \& Perumal, E. 2016. Tamarind seed coat ameliorates fluoride induced cytotoxicity, oxidative stress, mitochondrial dysfunction and apoptosis in A549 cells. Journal of Hazardous Materials 15(301): 554-565.

Babu, P.V. \& Liu, D. 2008. Green tea catechins and cardiovascular health: An update. Current Medicinal Chemistry 15(18): 1840-1850.

Bhadoriya, S.S., Ganeshpurkar, A., Bhadoriya, R.P.S., Sahu, S.K. \& Patel, J.R. 2018. Antidiabetic potential of polyphenolic-rich fraction of Tamarindus indica seed coat in alloxan-induced diabetic rats. Journal of Basic and Clinical Physiology and Pharmacology 29(1): 37-45.

Bhadoriya, S.S., Ganeshpurkar, A., Narwaria, J., Rai, G. \& Jain, A.P. 2011. Tamarindus indica: Extent of explored potential. Pharmacognosy Reviews 5(9): 73-81.

Bryan, N., Ahswin, H., Smart, N., Bayon, Y., Wohlert, S. \& Hunt, J.A. 2012. Reactive oxygen species (ROS)-a family of fate deciding molecules pivotal in constructive inflammation and wound healing. European Cells and Materials 24: 249-265.

Chen, L., Deng, H., Cui, H., Fang, J., Zuo, Z., Deng, J., Li, Y., Wang, X. \& Zhao, L. 2018. Inflammatory responses and inflammation-associated diseases in organs. Oncotarget 23: 9(6): 7204-7218.

Choosri, N., Tanasawet, S., Chonpathompikunlert, P. \& Sukketsiri, W. 2017. Apium graveolens extract attenuates adjuvant induced arthritis by reducing oxidative stress. Journal of Food Biochemistry 41(1): e12276.

Duque, G.A. \& Descoteaux, A. 2014. Macrophage cytokines: Involvement in immunity and infectious diseases. Frontiers in Immunology 5: 491.

Ferrero-Miliani, L., Nielsen, O., Andersen, P. \& Girardin, S. 2007. Chronic inflammation: Importance of NOD2 and NALP3 in interleukin- $1 \beta$ generation. Clinical and Experimental Immunology 147(2): 227-235.

Jayaraman, J., Jesudoss, V.A., Menon, V.P. \& Namasivayam, N. 2012. Anti-inflammatory role of naringenin in rats with ethanol induced liver injury. Toxicology Mechanisms and Methods 22(7): 568-576.

Komutarin, T., Azadi, S., Butterworth, L., Keil, D., Chitsomboon, B., Suttajit, M. \& Meade, B.J. 2004. Extract of the seed coat of Tamarindus indica inhibits nitric oxide production by murine macrophages in vitro and in vivo. Food and Chemical Toxicology 42(4): 649-658.

Leavy, O. 2014. Inflammation: regulating ROS. Nature Reviews Immunology 14(6): 357.

Lima, Z.M., da Trindade, L.S., Santana, G.C., Padilha, F.F., da Costa Mendonça, M., da Costa, L.P., López, J.A. \& Macedo, M.L.H. 2017. Effect of Tamarindus indica L. and Manihot esculenta extracts on antibiotic-resistant bacteria. Pharmacognosy Research 9(2): 195-199.
Martinez-Micaelo, N., González-Abuín, N., Terra, X., Richart, C., Ardèvol, A., Pinent, M. \& Blay, M. 2012. Omega-3 docosahexaenoic acid and procyanidins inhibit cyclo-oxygenase activity and attenuate NF- $\mathrm{B}$ activation through a p105/p50 regulatory mechanism in macrophage inflammation. Biochemical Journal 441(2): 653-663.

Medzhitov, R. 2010. Inflammation 2010: New adventures of an old flame. Cell 140(6): 771-776.

Mittal, M., Siddiqui, M.R., Tran, K., Reddy, S.P. \& Malik, A.B. 2014. Reactive oxygen species in inflammation and tissue injury. Antioxidants and Redox Signaling 20(7): 1126-1167.

Nakchat, O., Meksuriyen, D. \& Pongsamart, S. 2014a. Antioxidant and anti-lipid peroxidation activities of Tamarindus indica seed coat in human fibroblast cells. Indian Journal of Experimental Biology 52(2): 125-132.

Nakchat, O., Nalinratana, N., Meksuriyen, D. \& Pongsamart, S. 2014b. Tamarind seed coat extract restores reactive oxygen species through attenuation of glutathione level and antioxidant enzyme expression in human skin fibroblasts in response to oxidative stress. Asian Pacific Journal of Tropical Biomedicine 4(5): 379-385.

Park, M., Cho, H., Jung, H., Lee, H. \& Hwang, K.T. 2014. Antioxidant and anti-inflammatory activities of tannin fraction of the extract from black raspberry seeds compared to grape seeds. Journal of Food Biochemistry 38(3): 259-270.

Sandesh, P., Velu, V. \& Singh, R.P. 2014. Antioxidant activities of tamarind (Tamarindus indica) seed coat extracts using in vitro and in vivo models. Journal of Food Science and Technology 51(9): 1965-1973.

Schaible, A.M., Traber, H., Temml, V., Noha, S.M., Filosa, R., Peduto, A., Weinigel, C., Barz, D., Schuster, D. \& Werz, O. 2013. Potent inhibition of human 5-lipoxygenase and microsomal prostaglandin E2 synthase-1 by the anti-carcinogenic and anti-inflammatory agent embelin. Biochemical Pharmacology 86(4): 476-486.

Schieber, M. \& Chandel, N.S. 2014. ROS function in redox signaling and oxidative stress. Current Biology 24(10): R453-R462.

Sergent, T., Piront, N., Meurice, J., Toussaint, O. \& Schneider, Y.J. 2010. Anti-inflammatory effects of dietary phenolic compounds in an in vitro model of inflamed human intestinal epithelium. Chemico-Biological Interactions 188(3): 659667.

Sharma, J.N., Al-Omran, A. \& Parvathy, S.S. 2007. Role of nitric oxide in inflammatory disease. Inflammopharmacology 15(6): 252-259.

Sukketsiri, W., Tanasawet, S., Moolsap, F., Tantisira, M.H., Hutamekalin, P. \& Tipmanee, V. 2019. ECa 233 suppresses LPS-induced proinflammatory responses in macrophages via suppressing ERK1/2, p38 MAPK and Akt pathways. Biological and Pharmaceutical Bulletin 42(8): 13581365.

Suksomtip, M., Ukrisdawithid, S., Bhusawang, P. \& Pongsamart, S. 2010. Phenolic compound content, antioxidant and radical-scavenging properties of methanolic extracts from 
the seed coat of certain Thai tamarind cultivars. Journal of Food Biochemistry 34(5): 916-931.

Sundaram, M.S., Hemshekhar, M., Santhosh, M.S., Paul, M., Sunitha, K., Thushara, R.M., Naveen Kumar, S.K., Naveen, S., Devaraja, S., Rangappa, K.S., Kemparaju, K. \& Girish, K.S. 2015. Tamarind Seed (Tamarindus indica) extract ameliorates adjuvant-induced arthritis via regulating the mediators of cartilage/bone degeneration, inflammation and oxidative stress. Scientific Reports 10(5): 11117.

Tewtrakul, S., Itharat, A., Thammaratwasik, P. \& Ooraikul, B. 2008. Anti-allergic and anti-microbial activities of some Thai crops. Songklanakarin Journal of Science and Technology 30(4): 467-473.

Tungmunnithum, D., Thongboonyou, A., Pholboon, A. \& Yangsabai, A. 2018. Flavonoids and other phenolic compounds from medicinal plants for pharmaceutical and medical aspects: An overview. Medicines 5(3): 93.

Vadivel, V. \& Pugalenthi, M. 2010. Evaluation of nutritional value and protein quality of an under-utilized tribal food legume. Indian Journal of Traditional Knowledge 9(4): 791-797.

Wiart, C. 2007. Ethnopharmacology of Medicinal Plants: Asia and the Pacific. Totowa, NJ: Humana Press Inc.

Jirapa Puntarut \& Wanida Sukketsiri*

Department of Pharmacology

Faculty of Science

Prince of Songkla University

Songkhla, 90110

Thailand
Wipawadee Sianglum

Department of Microbiology

Faculty of Science

Prince of Songkla University

Songkhla, 90110

Thailand

Supita Tanasawet

Department of Anatomy

Faculty of Science

Prince of Songkla University

Songkhla, 90110

Thailand

Pennapa Chonpathompikunlert

Expert Center of Innovative Health Food

Thailand Institute of Scientific and Technological Research (TISTR)

Pathumthani, 12120

Thailand

*Corresponding author; email: wanida.su@psu.ac.th

Received: 2 August 2019

Accepted: 17 February 2020 